\title{
Gender Relations in Instrumental Folk Music in Slovenia
}

\author{
MOJCA KOVAČIČ \\ Institute of Ethnomusicology ZRC SAZU
}

\begin{abstract}
Gender studies are an important part of ethnomusicological research, but in Slovenia, not many studies or discussions have been dedicated to this topic. The position of a woman in the second half of the $20^{\text {th }}$ century in Slovenia is, on the one hand, strongly connected to the socialist social system and its policy of equality, but, on the other, the article also reveals control mechanisms that maintained hierarchical positions between genders. Several cases of women public instrumental practices are described, with a focus on a narrative of a woman bell chimer through which the complexity of gender relationships in bell chiming is discovered and explained.
\end{abstract}

Key words: gender position, music and gender, instrumental folk music, bell chiming

To understand musical identity when researching certain musical phenomena, it is also necessary to consider gender relations, which can be observed within the musical context or in a broader context. In society, gender relations are expressed in the form of power and they also affect hierarchical relationships in musical discourse. Cultivating the opposition between the sexes helps maintain a hierarchical system of male superiority in society (Butler 2001: 25). The marginal role of women is usually also connected to their social status. Along with changes in their position in society, one can also observe changes in gender relationships in musical culture.

Gender relationships also determine areas of research; ethnomusicologists started to emphasize gender issues in musical culture only in the $1970 \mathrm{~s}$ and the early 1980s. ${ }^{1}$ Gender studies have now become an important part of contemporary ethnomusicology, mostly revealing how gender dynamics in a particular culture affect musical culture, or how musical culture is strongly interrelated with gender roles in society. However, gender topics still gen-

\footnotetext{
${ }^{1}$ A similar paradigm is present in musicology discourse, where "the absence of women in the standard music histories is not due to their absence in the musical past" (Bowers and Tick 1987: 3).
} 
erally seem to inevitably be dealt with by women. ${ }^{2}$ Gender identity often facilitates equality between women researchers and the women researched, which also establishes a more dialogical atmosphere in which research is conducted. However, cross-gender perspectives remain marginalized.

Most ethnomusicology studies that have discussed important gender issues in musical culture have not specially emphasized instrumental music or musical instruments themselves (Doubleday 2008). ${ }^{3}$ Awareness of the importance of gender issues in instrumental music could be incorporated into new studies, and the gender-based meanings of past musical practices can be rediscovered. Reinterpreting old data collections and studies would offer an exciting new insight into musical practice.

This article presents how the control mechanisms that maintain hierarchical positions between genders are reflected in instrumental folk music and how political and social changes in the second half of the twentieth century affected the changing position of female musicians in Slovenian folk music. The relationship between gender identity that is ascribed to the instrument and gender identity of its performer, with an emphasis on bells as instruments with a strong male identity, is also discussed. The article continues by focusing on the example of a female bell chimer whose narrative reveals the experience she has had as a woman in a predominantly male musical domain.

\section{WOMEN INSTRUMENTALISTS IN SLOVENIAN MUSICAL TRADITION}

Literature on Slovenian folk music did not use a feminine form of the word for "folk musician" for a long time. However, even in today's literature the expression godka (as opposed to the masculine form godec, both "folk musician") is still not included in the officially sanctioned vocabulary of Slovenian. Slovenian musical tradition also shows a fairly clear division of roles in musical discourse: women prevail in vocal music, whereas men are active in both instrumental and vocal music. However, this division is primarily reflected in the public image of the gender division in music and the dominant position of men in public life. In contrast, a look into the private sphere shows a less

\footnotetext{
${ }^{2}$ For example, see the contributors in some of the leading anthologies on music and gender issues: Koskoff (1987), Magrini (2003), and Moisala and Diamond (2000).

${ }^{3}$ As the guest editor of a special issue of Ethnomusicological Forum (2008), Veronica Doubleday presented four case studies from different musical cultures that reveal a complex relationship between musical instruments and gender.

${ }^{4}$ Sometimes the expression godčevka is used, but in the past it referred to the wife of a godec (Kumer 1983: 153). This also reflects the subordination of a woman's identity to her husband's.
} 
sharp division and a mixing of the two. Some examples show that women did have a desire to take part in musical activities, but were not able to realize them in public life due to societal norms.

The presence of women is not only less expressed in Slovenian music tradition, but also less noticed by researchers. Woman instrumentalists are overlooked because of research approaches in ethnomusicology and the ideology of the media, focusing on the visible representatives of the local musical culture and highlighting male instrumentalists (Ceribašić 2001: 26-27). Moreover, in the past, Slovenian ethnomusicologists focused more on studies of music as a product and less on the social profile of its bearers and, until recently, women in folk instrumental music were not highlighted. Some findings on the role of women in instrumental folk music were noted by the ethnomusicologist Urša Šivic; based on field research in Šmartno ob Paki; she noted women's desire to be involved in music but inability to do so publicly because of patriarchal social norms (Šivic 2008: 161-189).

In Slovenia, women instrumentalists were only slightly more present in urban environments. ${ }^{5}$ At the end of the nineteenth century, tamburitza (Sln. tamburica) ensembles became very popular and were also widespread in rural areas (see Kumer 1983: 4). Women were also active in those ensembles and soon they started giving public performances. ${ }^{6}$ In spite of tamburitza ensembles being a partly institutionalized form of musical activity and as such more acceptable in society, they also transgressed gender roles in the musical life in the countryside. Female tamburitza ensembles were mostly led by men and perhaps only this and their activities as group musicians allowed them to be publicly accepted.

The postwar socialist era and the politics of equality, ${ }^{7}$ which substantially changed social norms, did somewhat affect the binary position of gender in folk music. By institutionalizing gender roles, women were given an opportunity to publicly take part in music. They typically started performing onstage

${ }^{5}$ In Western culture, gendered associations with musical instruments (along with sex-based stereotypes) still prevail in the sense that women mostly play the piano, the flute, and string instruments (Abeles 2009: 127-139; Pickering 2001: 623-643).

${ }^{6}$ The first female tamburitza ensemble in Ljubljana was established in 1892. It had fourteen members ("Prvi ženski" 1892: 404) and in the same year three of them already publicly performed at a reading society evening (“Čitalnica ljubljanska” 1892: 3). In 1892, women founded a tamburitza quartet in Šentjur near Celje ("Ženski tamburaški" 1892: 5). The girls from the Celje Sokol club performed publicly for the first time at a tamburitza concert in 1893 ("Tamburaški koncert" 1893: 3). Similar information from that time can be found for Brežice, Litija, and Vipava (Slovenia), Prosek (It. Prosecco, now in Italy), and other places.

${ }^{7}$ In 1948, the United Nations General Assembly adopted the Declaration on Human Rights, in which it also condemned discrimination on the basis of sex (Universal 1948, Article 2). The Declaration on the Elimination of Discrimination against Women, adopted in 1967, further promoted sexual equality. However, the postwar movement for sexual equality mainly affected public life in education and employment (Jeraj 2005) whereas in private life (especially in rural areas) women remained in an inferior position. 
at folk music festivals, for their families, and at music schools. According to existing field research, most women became familiar with the instruments in their childhood, when the division of gender roles was not yet so strong (i.e. Šivic 2008: 161-189; Oblak 2005).

The emancipation of women in instrumental music was enhanced by the founding of music schools as institutions open to everyone, regardless of gender. In this way, women in postwar social period could "legally" play instruments. However, it is also at music schools that the separation into "female" and "male" instruments is apparent. According to statistical data's, among the folk instruments that can be studied in formal music education, most girls (94\%) still play the zither and most boys (75\%) play the diatonic accordion ("Učenci, vključeni" 2009).

A special and fairly new occurrence is public performances by female groups that accompany their singing or accordion music (performed by men) with occasional musical instruments such as plastic gloves, rattles, scythes, graters, or bottles. These instruments allow them to more easily manifest their aspiration to perform instrumental music. They are easy to play, provide a simple rhythmic accompaniment to the melody, and require very little skill. These instruments are also not of high value or even treated as "real" instruments. Some of them were present in Slovenian musical tradition as occasional instruments played by anybody - women, children, or men - that stood in for skilled musicians when they were not available. But most of them are of recent origin, specifically made for the public stage performance.

In the last two decades the well-established pattern of Slovenian popfolk music as a male instrumental ensemble with female or male vocals has undergone some changes, as exclusively female groups (e.g., Vesele Štajerke, Zapeljivke) or women playing the diatonic accordion (e.g., Frajton Špela) have appeared. The "exotic" connotation of the woman instrumentalist is highlighted even more because of the rarity of women playing the accordion (the lead instrument in the genre), the bass, or the electric guitar. However, their participation can also be interpreted as a result of institutionalizing gender roles in instrumental music because the instruments mentioned above are taught in music schools or through private lessons.

The reasons for male dominance in instrumental music can be found in historical, cultural, and social patterns that put men in a dominant position, as well as in women's adjustment to their marginal position. The latter can explain why there is not enough information about women who took part in instrumental music activities: they were "affected" by the "syndrome of humility" (Lukšič Hacin 2003: 104), or underestimating their own music skills. Women's self-image in the past was often derived from patriarchal relationships, saturated by a gender dichotomy and internalized stereotypes. 
Women considered a large part of the activities in their lives to be unimportant, and therefore they denied them and tried to forget them. The women interviewed also often do not understand researchers' interest in their life experiences (Hladnik Milharčič 2003: 50), and therefore researchers need to be more persistent and put greater effort into their work to unearth these memories. Earning trust is a lengthy task and it takes time for women to internalize a positive opinion of their social role. An additional factor affecting the social perception of gender roles is the "syndrome of honor and shame" (Magrini 1998), when a certain task is deemed honorable if performed by a man but shameful when a woman performs it. ${ }^{8}$

\section{GENDER RELATIONS BETWEEN BELLS AND BELL CHIMERS}

Instruments also have their own identities, which are determined by their shape, sound, use, symbolic representations in legends, literature, and so on. People ascribe musical instruments with some personal characteristics or attributes of human nature, behavior or emotions along with gender. ${ }^{9}$ Their most common indicators are the social practices and the social context through which the associations of the instrument with a particular gender are established. Gender meanings can be incorporated into the instrument by the manufacturer's choice of materials, painting, or design, and they can be determined by naming and gendered description of parts of instruments. Instruments can be recognized as sexual symbols in folklore texts, and their gender can be metaphorically determined in myths, legends, and so on. The instrument and its performer can establish a single-gender or a cross-gender relationship. The first one is involved when the gender of the instrument is the same as that of the performer, and the latter when the genders are opposite (Doubleday 2008: 9-15).

As an example I highlight the relationship between bells and bell chimers, a domain where a strong male relation is established. Bells have a strong male identity: in Slovenian the word zvon "bell" is masculine, in baptismal rites a male patron is usually assigned to the bell, male identity is ascribed through inscriptions on the bell, and they mostly carry masculine personal

${ }^{8}$ The concept of "honor and shame", that is also seen in the Slovenian example of a woman bell chimer, is primarily attributed to Mediterranean culture: see Peristiany (1966), Magrini (1998), Moxnes (1996), and Gilmore (1985).

${ }^{9}$ This is particularly characteristic for bells: for example, naming the bell, the analogy of the baptism rite, inscriptions in the first person, naming parts of the bell (i.e., tongue, coat), and descriptions of the sound (i.e., the bell cries, sings, etc.). 
names. ${ }^{10}$ It is only at the level of family gendering ${ }^{11}$ that bells are ascribed a female identity, but even in this case the power relation between the genders is clear. In the case of the death of a member of a parish, bells of different size are rung. When a man dies, the biggest bell is rung, for women a mediumsized one, and for a child the smallest one. Here the sonic characteristic of the instrument plays an important role because low-pitched sounds are assigned to men and high-pitched sounds to women and children.

The traditional codex demanded a same-gendered relation of the bell with the musician. Thus, bells were primarily handled (during bell ringing or bell chiming) by men. Only recently has this code been changing, as evident from several examples of cross-gendered relationships between bells and female bell chimers. Even though "attitudes are changing about the cultural assignments of instruments by gender" (Doubleday 2008: 20), the relationship is unusual. In most world musical traditions, the cross-gendered relationship is common only between a male performer and a "female" instrument.

After 2000, along with the changes in the perception of gender roles in contemporary society, changes have occurred in the generational and gender structure of many bell-chiming groups as groups composed of women and children have become more active. A questionnaire administered from 2005 to $2009^{12}$ shows that among 181 participants, $11 \%$ are female primarily between five and twenty years old.

\section{BELL CHIMING, CHRISTIANITY AND GENDER}

Most world religions are closely connected with a traditional ideology of gender. Because religion is associated with gender position and power in society, it also has strong links to musical discourse. To understand the relationship of bells to gender issues, one must not disregard the context of Christianity. Bell chiming is a part of religious rituals, which have always been the prerogative of men. Thus, one can add the aspect of male domination in religion to the preceding reasons for the marginal position and (past) inactivity of women in the musical tradition involving bells.

Social aspects of the division of labor between the sexes have also had an impact on the social order within church-related activities. Such a division

\footnotetext{
${ }^{10}$ The world's most famous bells carry masculine names, such as London's Great Paul, Big Ben of Westminster, and Oxford's Great Tom (Camp, quoted in Doubleday 2008: 11).

${ }^{11}$ Family-based gendering is defined on the basis of the size of the instrument and corresponds to the pitch of the instrument (Doubleday 2008: 14).

12 The questionnaire was part of my doctoral dissertation entitled Pritrkavanje - etnomuzikološka fenomenologija pojava in njegova vključenost v slovenski in evropski prostor (Bell Chiming: The Ethnomusicological Phenomenology of the Practice and Its Inclusion in Slovenia and Europe) (Kovačič 2009).
} 
was more noticeable in the past; however, it is still present today. Women are largely responsible for the decor in the church (cleaning, flowers, and candles), and men take the role of keepers of the keys, altar boys (today also altar girls), bell ringers, sextons, or bell chimers. Within the socialist policy of gender equality, in addition to singing in the church choir, women could participate in musical activities such as organ playing or bell chiming, although this was not very frequent.

Based on oral sources (Spodnji Dolič 2007; Smlednik 2005), two newspaper articles (Jakše 2001: 18; Jerman 2008: 5) and some electronic sources, it can be concluded that women were slightly more frequently active in bell chiming, but less visibly exposed. Women usually acquired the right to participate in bell chiming through their family ties. In most cases, chiming women were sextons' daughters or wives. Taking care of the church was officially in the male domain, but due to their other commitments, some of their church obligations (especially ringing the bells three times a day, which was a binding commitment) was often taken over by women and children.

Most of those female bell chimers started bell chiming in their childhood, when the division of gender roles was not so strong. Only recently, when bell chiming began acquiring new contextual and functional dimensions such as bell-chiming schools, competitions, public festivals, and so on, has the activity of women in bell chiming been on the increase once again. However, one must also not neglect the required physical strength needed to move the clapper, which is also a physical reason for the exclusion of women from bell chiming. Today this is often facilitated by levers attached to clappers and by new, lighter clappers.

\section{THE STORY OF A WOMAN BELL CHIMER}

I present the case of the emancipation of a woman in the bell-chiming domain at a time when this was still an exception. ${ }^{13}$ Through her story and especially through her own words about her musical involvement, the previously stated reasons for women's marginality in instrumental music are corroborated.

The bell chimer Marija Oblak (born in 1929) lived near the church in Smlednik before and after she was married, which was the key factor in her participation in bell ringing and bell chiming. She is modest in her description of her first contacts with instrumental music. These go back to her childhood, when she played her brother's guitar; her brother showed her some of

${ }^{13}$ I present only her social position within the bell-chiming domain, while her musical activity, bell chiming style or repertoire is no different from the one represented by male bell chimers. 
the basics, and sometimes, when the church was empty, she secretly played the organ:

We didn't use to have these opportunities. I tried, but not much. My brother had a guitar. Before... I went to wind the clock, and then I played the organ in the church. No, I didn't [play] much, not so much as to say that I knew anything. (Oblak 2005)

As a child, Marija often joined her father and observed bell chiming by adults. She then used to imitate bell chiming with her peers as part of child's play.

With the onset of World War II, the tradition of bell chiming was interrupted in many places, including Smlednik. After the war, there was no bell chiming in Smlednik either: some bell chimers did not return from the army, and others did not dare to chime due to the ban by the postwar authorities; however, this was the first opportunity for Marija. ${ }^{14}$

The men just vanished, there was no one. You know, whatever the government dictated. The boys started... that was right after the war, when we had that freedom. ${ }^{15}$ And then I started bell ringing and bell chiming, everything. (Oblak 2005)

Marija Oblak first rang and chimed the bells in 1946, when she was seventeen years old. First she started bell chiming with her father, who soon stopped because of old age and illness. Later she chimed with the sexton because bell chiming called for at least two chimers, but she says he was not very skilled, and so she had the main role in chiming.

A milestone in her activities was her wedding in 1957, an event which many women in other cases mention as the reason for stopping their musical activities. Marija moved to her husband's house and "lost" her family, which was crucial in supporting her musical activity in the past. She was now "subordinated to multiple authorities" (Shehan 1987: 46) such as her mother-in-law, father-in-law, and brother-in-law, who did not support her musical involvement. Some years later, bell chimers from other surrounding churches started to arrive at Smlednik and they soon took over bell chiming in the parish church. Good organization and the unity of the Smlednik bell

\footnotetext{
${ }^{14}$ In a similar way, the tradition of tamburitza playing was maintained by the girls from Šmihel (Ger. Sankt Michael), a village of Slovenian minority now living in Austrian Carinthia. The girls took over the tradition because in 1939 "many boys were already called up to serve in the army and the tamburitza would just lie there if not played by girls" (Gabriel and Lavrenčič 2005: 121).

15 The period after World War II was referred to as freedom (Sln. svoboda), but it had nothing to do with actual individual freedom, since that was the period of "illusory bourgeois freedom" (Močnik 1984: 12).
} 
chimers also prevented her from joining their group. She finally "seized" the opportunity to chime bells in their absence.

Marija's most active period corresponds to the sociopolitical situation in postwar Yugoslavia when women were made formally (by way of a constitutional act) equal with men and they obtained legal protection in several areas of social life. However, the politics of equality, which was being implemented on several levels, was ambiguous. The postwar ideal put the woman in the position of a worker and a mother, where she was supposed to be "persistent and confident, but at the same time simple, modest, and willing to make sacrifices" (Vodopivec 2001: 71). Marija was never employed, so the key form of women's emancipation in the postwar period did not extend into her private life, saturated with patriarchal patterns. Her "persistence and confidence" was shown, along with the general approval of her family, but the change in her marital status put her in a position of a "simple, modest, and willing-to-make-sacrifices" mother, subjected to her family obligations: "After that, once you get married, you slowly drop out. You know, work and children and everything comes, and then you can't do it" (Oblak 2005).

There is another aspect that can help in understanding the role women played in bell chiming. Bell chiming can only partly be placed in the area of public musical expression because it is invisible to the public due to its specific venue. In bell chiming, only sound is publicly exposed, not the personal characteristics (gender) of the performer. So, hiding the gender helped to change Marija's status in bell chiming. Therefore Marija was only able to chime bells in her home village. She observed bell chiming outside her own church only once, but did not take part because she believed that as a woman she would be "frowned upon". In such way, Marija "transgressed the patriarchal norms on an individual level" (Hofman 2011: 109), while social boundaries remained unchanged.

In addition to the control of the family, an important means of social control over the position of women was gossip. Women that were too independent and ambitious were always the subject of gossip more frequently than others (Vodopivec 2001: 75) and thus socially marked, which called for caution: "You know, as a woman everyone looked at me a bit, and then I didn't put myself forward. I've never wanted to stand out" (Oblak 2005).

As a woman, Marija's participation in instrumental music was only justifiable to some as necessity because there were no other (male) bell chimers and the tradition would have thus stopped. Marija therefore received the opportunity for bell chiming at a time when the political position of the authorities considered bell chiming an inferior and unworthy activity. The concept of honor and shame is seen in the fact that when bell chiming became worthy again men took over the chiming and she withdrew. She only 
chimed or rang the bells again when she was invited; that is, when there were not enough bell chimers.

To draw things to a close, I again highlight the position of the researcher in such cases: often the most demanding aspect of research is to find the unconventional position of the interlocutor. My position as a female researcher contributed to Marija's gradual subjectivization of her story through my understanding of her position in society and admiration of her unusual role in bell chiming. At first, Marija presented herself in the light of the socially accepted position of a woman in music and presented her activity as less important and not worthy of my attention. In the course of our conversations and because of my interest in the topic, her position as a bell chimer increased in importance and supported her opinion of her activity as an important contribution to social life. The conversation may have even contributed to the confirmation of her position as a bell chimer, when her wish to chime the bells once again came true in 2007. She was invited by the local (male) bell chimer to chime in the church tower of her home church.

\section{CONCLUSION}

The study of gender relations in instrumental music reveals that the predominant male identity of musical instruments "supports the concept of male authority and order" (Doubleday 2008: 12) in a still predominantly male-oriented society. Even in the West, where women's emancipation in the social domain has been on the rise for some time now, and where the (formal) social constraints between genders are blurred, it seems that woman are otherwise interfering with the male domain, but still do not transcend gender boundaries in the instrumental musical domain.

Musical practices could be privileged venues "for the public construction and representation of individual gender identity" (Magrini 2003: 5) and as such offer women an opportunity to exceed traditional gendered social frameworks. Even today, when the traditional codes on the marginal position of women in social domains should be transcended, women in Slovenian instrumental folk music mostly negotiate their position only within an institutional framework. They find their refuge in formal forms of musical activity such as playing folk instruments in music schools, as part of public performances at folk music festivals, or being bell chimers at chiming festivals, competitions, or schools. Therefore a story like Marija's still remains the story of an exceptional individual. 


\section{REFERENCES AND SOURCES}

Abeles, Hal. 2009. "Are Musical Instrument Gender Associations Changing?" Journal of Research in Music Education 57/2: 127-139. [http://dx.doi.org/10.1177/0022429409335878]

Bowers, Jane and Judith Tick. 1987. Woman Making Music. The Western Art Tradition, 11501950. Urbana, IL: University of Illinois Press.

Butler, Judith. 2001. Težave s spolom. Feminizem in subverzija identitete. Ljubljana: Škuc.

Ceribašić, Naila. 2001. "In between Ethnomusicological and Social Canons. Historical Sources on Women Players of Folk Music Instruments in Croatia". Narodna umjetnost 38/1: 21-40.

“Čitalnica ljubljanska”. 1892. Slovenski narod, 14 November. 25/260: 3.

Doubleday, Veronica. 2008. "Sounds of Power. An Overview of Musical Instruments and Gender". Ethnomusicology Forum 17/1: 3-39. [http://dx.doi.org/10.1080/17411910801972909]

Gabriel, Hanzi and Vlasta Lokar Lavrenčič. 2005. Po sledeh tamburaštva na Koroškem. Klagenfurt: Krščanska kulturna zveza and Mohorjeva založba.

Gilmore, David, ed. 1987. Honor and Shame and the Unity of the Mediterranean. Washington, DC: American Anthropological Association.

Hladnik Milharčič, Mirjam. 2003. "Slovenian Women’s Stories from America”. Dve domovini Two Homelands 17: 47-60.

Hofman, Ana. 2011. Staging Socialist Femininity. Gender Politics and Folklore Performance in Serbia. Leiden: Brill. [http://dx.doi.org/10.1163/ej.9789004191792.i-148]

Jakše, Tone. 2001. "Kdo klenka pri Sveti Trojici?" Dolenjski list 52/10: 18.

Jeraj, Mateja. 2005. Slovenke na prehodu v socializem. Vloga in položaj žensk v Sloveniji 19451953. Ljubljana: Arhiv Republike Slovenije.

Jerman, Vladimir. 2008. "Pri sto dveh letih igra na zvonove”. Slovenske novice, 12 September, 5.

Koskoff, Ellen, ed. 1987. Women and Music in Cross-Cultural Perspective. Urbana, IL: University of Illinois Press.

Kovačič, Mojca. 2009. Pritrkavanje. Etnomuzikološka fenomenologija pojava in njegova vključenost v slovenski in evropski prostor. [PhD thesis]. Nova Gorica: [Kovačič].

Kumer, Zmaga. 1983. Ljudska glasbila in godci na Slovenskem. Ljubljana: Slovenska matica.

Lukšič Hacin, Marina. 2003. "Vloga izseljenk za ohranjanje nacionalne identitete v kontekstih, ki jih konstituirajo patriarhalni odnosi in spolna dihotomija". Dve domovini - Two Homelands 18: 97-112.

Magrini, Tullia. 1998. “Women's 'Work of Pain' in Christian Mediterranean Europe”. Journal of Musical Anthropology of the Mediterranean 3. Available at: http://umbc.edu/MA/index/ number3/magrini/magr0.htm (accessed 5 January 2015).

Magrini, Tullia, ed. 2003. Music and gender. Perspectives from the Mediterranean. Chicago: University of Chicago Press.

Močnik, Rastko. 1984. "V boju za svobodo javne besede-danes". Karl Marx. Cenzura in svoboda tiska. Ljubljana: Republiška konferenca ZSMS, Univerzitetna konferenca ZSMS [KRTKnjižnica revolucionarne teorije], 7-22.

Moisala, Pirkko and Beverly Diamond, eds. 2000. Music and Gender. Urbana, IL: University of Illinois Press.

Moxnes, Halvor. 1996. "Honor and Shame". The Social Sciences and New Testament Interpretation. Peabody, MA: Hendrickson, 19-40.

Oblak, Marija. 2005. Sound Recording of the Interview. Archive of GNI ZRC SAZU, GNI DAT 318. 
Peristiany, John G., ed. 1966. Honour and Shame. The Values of Mediterranean Societies. Chicago: University of Chicago Press.

Pickering, Samantha and Betty Repacholi. 2001. "Modifying Children's Gender-typed Musical Instrument Preferences. The Effects of Gender and Age". Sex Roles. A Journal of Research, 45/9-10: 623-643. [http://dx.doi.org/10.1023/A:1014863609014]

"Prvi ženski tamburaški zbor". 1892. Kmetijske in rokodelske novice, 2 Decemeber, 50/49: 404.

Shehan, Patricia K. 1987. "Balkan Women as Preservers of Traditional Music and Culture". Women and Music in Cross-Cultural Perspective. Urbana, IL: University of Illinois Press, 45-53.

Smlednik. 2005 (25. 5. 2005). Sound recording from the Archive of GNI ZRC SAZU.

Spodnji Dolič. 2007. (1. 2. 2007). Sound recording from the Archive of GNI ZRC SAZU.

Šivic, Urša. 2008. "Ljudska pesem, glasba in ples v Šmarski okolici”. In Šmartno ob Paki. Matjaž Šalej and Emil Šterbenk, eds. Velenje: Erico, Inštitut za ekološke raziskave, 161-189.

"Tamburaški koncert celjskega Sokola”. 1893. Slovenski narod, 6 December, 26/280: 3.

"Učenci, vključeni v program glasba in ples, po uspehu pri posameznih predmetih, Slovenija, konec šolskega leta". 2009. Statistični urad republike Slovenije. Available at: http://pxweb. stat.si/pxweb/Dialog/varval.asp?ma=0909603S\&ti=\&path=./Database/Dem_soc/09_ izobrazevanje/05_09096_osn_glasb_izobraz/\&lang=2 (accessed 10 January 2015).

Universal Declaration of Human Rights: 1948-2008. Available at: http://www.varuh-rs.si/index.php?id=102\&L=6 (accessed 10 January 2015).

Vodopivec, Nina. 2001. "Sem delavka, mati in gospodinja”. Etnolog 11/62: 69-90.

“Ženski tamburaški kvartet”. 1892. Slovenski narod, 24 December, 25/294: 5.

\section{RODNI ODNOSI U INSTRUMENTALNOJ NARODNOJ GLAZBI U SLOVENIJI}

Rodni su studiji važan dio etnomuzikologije, međutim u Sloveniji se tek mali broj istraživanja i rasprava bavi tim pitanjem. Položaj žene u drugoj polovici 20. stoljeća u Sloveniji čvrsto je vezan uz socijalistički društveni sustav i njegovu politiku jednakosti, ali se u radu razotkrivaju i kontrolni mehanizmi koji su održavali hijerarhijske odnose između rodova. U radu su prikazani neki slučajevi javnih instrumentalnih praksi žena.

Ključne riječi: rodni položaj, glazba i rod, instrumentalna narodna glazba, zvonarstvo 